Relations industrielles

Industrial Relations

\title{
Gérin-Lajoie, Jean, Trois usines mexicaines
}

\section{Peter Warrian}

Volume 54, numéro 4, 1999

URI : https://id.erudit.org/iderudit/051279ar

DOI : https://doi.org/10.7202/051279ar

Aller au sommaire du numéro

Éditeur(s)

Département des relations industrielles de l'Université Laval

ISSN

0034-379X (imprimé)

1703-8138 (numérique)

Découvrir la revue

Citer ce compte rendu

Warrian, P. (1999). Compte rendu de [Gérin-Lajoie, Jean, Trois usines mexicaines]. Relations industrielles / Industrial Relations, 54(4), 826-828. https://doi.org/10.7202/051279ar

Tous droits réservés (C) Département des relations industrielles de l'Université Laval, 1999
Ce document est protégé par la loi sur le droit d'auteur. L’utilisation des services d'Érudit (y compris la reproduction) est assujettie à sa politique d'utilisation que vous pouvez consulter en ligne.

https://apropos.erudit.org/fr/usagers/politique-dutilisation/ 
de production, former des jeunes sans expérience, plutôt que d'embaucher des personnes ayant déjà une expérience professionnelle, cherchant ainsi «à déstructurer les formes anciennes de culture ouvrière en cassant les collectifs ouvriers et, par-là, empêcher l'émergence des revendications collectives ".

JEAN GÉRIN-LAJOIE École des H.E.C. Montréal

\section{Trois usines mexicaines}

par Jean GÉRIN-LAJOIE, Montréal : École des hautes études commerciales, Centre d'études en administration internationale, 1999, 141 p., ISBN 2-9202-9671-X.

Students of industrial relations have tended to examine the impact of globalization on industrial relations in terms of linear views such as the "Race to the Bottom" in employment relations and labour standards. Jean Gérin-Lajoie in this innovative and important book examines the other side of the story: How do work relations actually work on the ground? What are the different perspectives of supervisors and workers? What are their levels of satisfaction? What are their expectations for the future?

The Golden Age of the post-war boom, rising living standards, expanding opportunities and the social safety net was based on about 20 countries comprising about 600 million people. The world economy is now comprised of 200 countries and 6 billion people. The hopes and prospects of success of workers in these three plants, as revealed by the author, give us critical indications of where we are going and what's next.

The research objective of the study is to examine the realities of social relationships in the context of large high tech industries. How is supervisory authority exercised? How is work organized? What different perceptions are held by supervisors and workers? How do these factors combine in the impact of N $\Lambda F T \Lambda$ and globalization?

The sites chosen for the case studies are all large industrial facilities characterized by the use of high tech manufacturing. The three factories are a GM auto plant, a Chrysler truck plant and an Imexsa steel mill. No claim is made that these plants or the results of the study can be taken as representative of all Mexican manufacturing, let alone Mexican society. All are part of large multinational corporations. None are Mexican owned. However, this does not subtract from their importance and the relevance of the author's insights.

The methodology employed was a large number (200) structured interviews with a representative sample of shopfloor and management employees, using a standard interview instrument. Chapters presenting results on the individual plants are followed by comparative analysis of the group as a whole.

The overall results and conclusions are focus on demographics, satisfaction levels, perspectives on personal futures and the perspectives on the future of Mexican society.

In regard to demographics, the two older factories, GM and Imexsa, as expected have older average age (29) and service workers ( 7 years). The Chrysler plant is much younger (23) and shorter term (23 months). The recruitment policies favour younger recruits (average 21 years). However, this must be understood in the context of the huge population of young people in Mexican society - over $50 \%$ under 18 .

The rate of married workers is also higher at the older plants : GM, 83\% and Imexsa, $76 \%$, compared to Chrysler at $54 \%$.

The educational level at all three plants is about the same, $10-11$ years of 
formal education. The steel plant has a somewhat bifurcated education levels with higher levels in supervisory and technical, and lower educational levels in the unionized workforce.

Satisfaction levels are more nuanced and revealing. This is perhaps among the most important findings of the study. In overall satisfaction, the GM plant was highest, Chrysler next and Imexsa significantly lower. Very high levels of satisfaction $(93 \%)$ were reported in regard to work organization. Workflow in the steel mill was very intense, but more intermittent. In the auto plants, the line flowed continuously with only occasional stoppages. There was mitigated approval in the auto plants. There was bare approval in the steel plant. The latter dissatisfaction mostly related to the requirement of protective equipment and clothing.

In the rapport between workers, two trends were revealed. One was the amount of extra work due to chronic absenteeism. This was counter-balanced by feelings of solidarity and social cohesion. With one exception - a foreman at $\mathrm{GM}$ - there was no evidence found of peer pressure regarding reduction of absenteeism. In fact, individual workers seem to view it as "this week it's his turn, next week will be my turn". Workers might complain about the effects of absenteeism, but not about its causes. Absenteeism appears to be embedded in the work culture, and somewhat reinforced by legislation.

All three plants are large, successful enterprises with expanding production. There are very high levels of overall satisfaction by supervisors and workers together, reflected as well by their spouses. The satisfaction levels of spouses were $95 \%$, though with concerns at the steel plant about dangerous work and at the Chrysler plant over long hours.

The satisfaction levels over employment and work organization were also revealing. The GM plant had by far the highest satisfaction levels (87\%). This was related to new human resource manage- ment policies introduced that included election of Team Leaders and shop stewards and an active policy of employee involvement. The Chrysler plant $(66 \%)$ and the steel mill (44\%) had more traditional, hierarchical authority systems. There was, however, an indication of some levels of dissatisfaction in each factory at the time of the study. At the auto plants, the issue was the high levels of overtime. At the steel plant, it was unsafe working conditions.

In regard to the expectations for their personal future, workers at the factories were near unanimous in feeling the future was good to great. About $25 \%$ defined their future prospects solely in personal terms. The large majority - GM (72\%), Chrysler (62\%) and Imexsa (50\%) - spontaneously linked their personal future prospects to that of the company. A measurable minority saw their future as separate from that of the company GM (2\%), Chrysler (14\%) and Imexsa $(31 \%)$. In other words, the latter group expected to be leaving their employer in the future, for reasons of layoff, accident or health. This was particularly so for the steel mill workers. The GM plant has a level of "enthusiasm" related to its change in the mentality of the shop floor and overcoming a conflictual past. The author sees this as a significant break with the past culture of mistrust of institutions in Mexican society.

The future levels of satisfaction are not guaranteed, in the author's view. Problems may arise. For instance, the assembly lines will continue, but workers may not be able to move out of their current jobs and GM's innovations may run out of steam.

The future of Mexican society is also reflected in the plants and the attitudes of the work force. There is near unanimous agreement among workers and supervisors in these plants that Mexico has a bright future. The author agrees. He does not see how this conclusion can be doubted. The Imexsa steel plant is owned by ISPAT, a growing power in the global 
steel industry. The Chrysler plant makes small trucks - a booming market in North America. The GM plan makes Cavalier and Chevy models for North and South America and GM is making huge efforts to regain its traditional market share.

However, all three plants have some common features that could be problems in the future. All three factories heavily depend on exports, primarily to the USA. Workers and supervisors in the Mexican plants are fully aware that they are part of the new globalized economy. Their prospects are inherently linked to the prospects of the American economy and they all know it.

The author emphasizes that the future success of these factories cannot separated from the future prospects for
Mexican society as a whole. At the time of the study, inflation was running at $15 \%$. Some 700,000 new jobs had been created, but a million are required to contain the demographic explosion in Mexican society. Otherwise, underemployment and impoverishment will be the inevitable result. High crime rates and conflict in the labour movement are also well known.

The previous stability in Mexican society rested on a balance between political and public actors. Confidence and trust in the traditional power centers have now been lost. We do not know how this will work out for the system. The author expresses hope and confidence that they can work it out. So should we all.

PETER WARRIAN

University of Toronto

The State of Working America, 1998-99

Lawrence MISHEL, Jared BERNSTEIN, and John SCHMITT, Ithaca, N.Y.: Cornell University Press, 1999, 480 p., ISBN 0-8014-3613-3 (cloth), ISBN 0-8014-8582-7 (paper).

Unprecedented growth! Rocketing stock prices! Unbelievably low unemployment! In recent years, the US economy has inspired not only excessive superlatives, but also envy throughout the world. The rush to "Americanize" labour market structure is on and policy makers and economists extol the virtues of liberalized markets, weak unions, low standards on training and wages, reductions in the welfare state, and empowered capital. But before you run out to follow the trend, The State of Working America 1998-99 should be required reading.

Since 1988, this report has been prepared biennially and released by the Economic Policy Institute, a Washington DC think-tank. With its abundant statistics, detailed analyses, and intemational comparisons, The State of Working America 1998-99 provides a more comprehensive picture than any other resource of what is really going on in the United States economy, who has gained from it, and why it is happening.

The book can be used simply as a statistical almanac - it provides the numbers on wages, living standards, and inequality. Placing the US miracle in a historical context, and looking carefully at who is winning and who is losing in recent years, the authors paint a much more complete picture of the state of working families in the US. Take, for example, the fact that the years of boom have produced only $0.1 \%$ increase in family income (p.40). And while it is finally widely accepted that income inequality grew dramatically over the 1980 's in the States (and the authors deserve credit for pushing the evidence on that), The State of Working America shows dramatic growth in income inequality extended into the 1990s. The evidence on hours of work per family presents an equally compelling story. From 1989 to 1996, the median-income, married cou- 